\title{
MEMÓRIA E HISTÓRIA DA EDUCAÇÃO MEDIEVAL: UMA ANÁLISE DA AUTENTICA HABITA E DO ESTATUTO DE SORBONNE
}

\author{
Terezinha Oliveira*
}

Recebido em: 26 de maio de 2009

Aprovado em: 23 de junho de 2009

\begin{abstract}
*Dra. em História pela Universidade Estadual Paulista Júlio Mesquita Filho (UNESP) com Estágio de PósDoutorado pela Universidade de São Paulo (USP). Professora do Departamento de Fundamentos da Educação e do Programa de Pós-graduação em Educação da Universidade Estadual de Maringá (UEM). Bolsista de Produtividade em Pesquisa do CNPq (PQII).E-mail: teleoliv@gmail.com.
\end{abstract}

Resumo: O objetivo deste trabalho é tecer considerações sobre a história e a memória de homens de saber, entre os séculos XII e XIII, no Ocidente latino, a partir de dois documentos. O primeiro é o Authentica Habita (1155/58). Este documento foi editado pelo imperador Frederico Barbaroxa (1122-1190). Nele, o Imperador do Sacro Império Romano-Germânico (1152-1190) apresentou uma lei, considerada a primeira, para defender os interesses dos homens de saber - ou daqueles que se dedicavam ao conhecimento. O segundo é o Estatuto da Universidade de Sorbone (1274). Este documento tinha como objetivo regular a vida dos estudantes no lócus universitário. Para a análise dos dois documentos que procuravam proteger e regulamentar a vida de homens do saber seguiremos os caminhos da história social, sob a perspectiva da longa duração. Entendemos que os processos históricos, os fenômenos educativos e as instituições escolares e universitárias de outros tempos históricos podem servir de pontos de partida para uma reflexão dos homens contemporâneos diante das suas questões.

Palavras-chave: História da educação. Idade média. Escolas. Universidades.

\section{MEMORY AND HISTORY OF MEDIEVAL EDUCATION: AN ANALYSIS OF AUTHENTICA HABITA AND THE STATUTE OF SORBONNE UNIVERSITY}

\begin{abstract}
The purpose of this study is to use two relevant documents to make considerations about the history and memory of scholars who lived between the XIIth and the XIIIth centuries, in the Latin West. The first document, named Authentica Habita (1155/58), was edited by the emperor Frederico Barbaroxa (1122-1190). In this document, the Emperor of the Sacred Roman-Germanic Empire (1152-1190) presented a law, considered as the first one to defend the interests of scholars. The second document was the Statute of Sorbonne University (1274), a document which aimed at regulating the students' life within the university locus. For the analysis of both documents, written with the purpose of protecting and regulating the life of scholars, the path of social history will be followed, on a long-term perspective. Such retrospective is based on our view that historical processes, educational phenomena, as well as schools and universities of other historical periods may serve as starting points for contemporary men to reflect upon different subjects.
\end{abstract}

Key words: History of education. Middle ages. Schools. Universities.

O objetivo deste trabalho é analisar a história e a memória de homens de saber, entre os séculos XII e XIII, no Ocidente latino, a partir de dois documentos. O primeiro é o Authentica Habita (1155/58). Este documento foi editado pelo imperador Frederico Barbaroxa (1122-1190). Nele, o Imperador do Sacro 
Império Romano-Germânico (1152-1190) apresentou uma lei que teria sido a primeira a defender os interesses dos homens de saber - ou daqueles que se dedicavam ao conhecimento. O segundo é o Estatuto da Universidade de Sorbone (1274), documento elaborado no interior da própria Universidade e tinha como objetivo regular a vida dos estudantes no lócus universitário.

Para a análise dos documentos que procuravam proteger e regulamentar a vida de homens do saber nos séculos XII e XIII seguiremos as proposições apresentadas pelo pensador português do século XVI Jeronymo Osório (Lisboa, 1506 - Tavira, 20 de Agosto de 1580) que nos ensina o quão a história é importante para a formação das pessoas.

Bem que eu seja do ânimo, integérrimo Príncipe D. Henrique, de que nada há mais proveitoso do que a História para adquirir prudência, nem mais poderoso que ela para despertar virtudes, mais saudável para sanear as feridas da República, nem mais aprazível para o deleitamento da vida; [...]. (OSÓRIO, 1804, v. I, p. 3)

Osório afirma que nada é mais proveitoso do que a história para tornar os homens prudentes; nada mais poderoso para despertar as virtudes; nada mais saudável para sanear as feridas da República, leia-se, hoje, sociedade; nem mais aprazível para o deleite da vida. Mais adiante, o autor insiste sobre a importância da prudência adquirida pelo conhecimento da História. "E se de homem sizudo he avisarse com o perigo alheio [...]”. (OSÓRIO, 1804, v. I, p. 4). Do ponto de vista do autor, o homem prudente é aquele que, conhecendo a experiência alheia, aprende a prevenir-se observando o perigo que outros já correram. Não é outra a opinião de Duarte Ribeiro de Macedo, também português, que cita um verso latino "Felix, quem faciunt aliena pericula cautum”: "É bem aventurado quem com o perigo alheio se faz precavido”. (MACEDO, 1975, p. 176)

Assim, por consideramos, tal como Osório, que a história e a memória de outros tempos são exemplos salutares que podem nos propiciar a prudência necessária para nosso agir cotidiano, especialmente no âmbito da sala de aula, é que retomamos estes dois documentos relativos à vida dos intelectuais medievais.

Ambos os documentos nos apresentam aspectos importantes da organização estudantil no medievo porque, ainda que sejam de séculos distintos e originados de autoridades específicas, indubitavelmente, nos fornecem elementos que nos permitem recuperar fragmentos da história e da memória de homens que se dedicaram ao saber. Esses documentos revelam a existência de dois aspectos que permanecem ainda vigentes em nossos espaços de saberes.

A Authentica ... expressa a estreita relação existente entre o poder e os homens de saber, pois é um imperador que se preocupa em proteger os mestres 
e alunos, em uma época (século XII) que estes não haviam se organizado em corporação, não tinham seus estatutos, permaneciam muitas dúvidas sobre os papeis destes personagens na sociedade. Não podemos, por isso, falar em intelectuais, nos moldes que assumiram no século XIII. Permanecia ainda na sociedade uma questão crucial: afinal, o saber é um dom divino ou é fruto do conhecimento? Essa dúvida aparece de forma explicita na História das Minhas Calamidades de Pedro Abelardo, quando reflete e conclui que as tragédias que abateram sobre ele resultam de sua soberba em não reconhecer que sua sabedoria provinha de Deus e não dele próprio.

O segundo documento, o Estatuto de Sorbonne, expressa um outro momento do saber medievo (segunda metade do século XIII) no qual a função ou o papel dos intelectuais já estavam mais claramente definidos. A sociedade aceita e legitima, com mais tranqüilidade, a função de mestre e de alunos. Todavia, ainda que os dois documentos datem de séculos distintos, eles podem, sob o olhar da história da educação, ser considerados pela mesma lente/ótica, pois ambos revelam dois aspectos que são inerentes aos homens de saber medievos: a ambiência citadina e a estreita relação do conhecimento com o poder.

Nesse sentido, nosso propósito é compreender de que maneira um estudo sobre os documentos concernentes ao ensino e aos intelectuais medievais nos possibilita, no campo da história da educação, estabelecer a estreita relação entre passado/presente no que diz respeito às atividades universitárias.

Para nós, historiadores da educação, a concepção de temporalidade é importante para compreender o movimento da história, por conseguinte, as práticas educativas. No caso deste texto, em particular, esta noção é fundamental, pois dispomos a estudar uma prática que, ainda que surgida no seio do Ocidente medieval latino, entre os séculos XII e XIII, permanece presente e atuante no ensino até os dias atuais. Afinal, o lócus de onde saem nossos discursos e pesquisas tem a mesma designação oriunda do medievo: escolas para o século XII; universidade para o século XIII. Onde atuamos? Se não nas escolas e nas universidades? A modernidade e a contemporaneidade não criaram outra definição para as instituições do conhecimento, mas preservaram as mesmas oriundas do medievo. Todavia, ainda que as instituições possuam os mesmos nomes, as atuais são muito distintas das do medievo e, sob este aspecto de permanência e mudanças, ganham importância as considerações de Le Goff sobre o conceito de temporalidade.

Compreender o tempo <<é essencialmente dar provas de reversibilidade $>>$. Nas sociedades, a distinção do presente e do passado (e 
do futuro) implica essa escalada na memória e essa libertação do presente que pressupõem a educação e, para além disso, a instituição duma memória coletiva a par da memória individual. (LE GOFF, 2003, p. 210)

Com efeito, ao analisar o passado é preciso considerar também as diferenças temporais existentes entre a época do objeto de estudo e o tempo presente vivido por nós. Todavia, as especificidades de cada uma das épocas históricas possibilitam a conservação da memória coletiva e individual e são estas duas naturezas de memória que nos permitem nos entender como sujeitos dos processos de construções sociais. É a preservação desta memória que nos concede as identidades particular e coletiva, sejam elas dos homens medievais ou contemporâneos. Todavia, essa memória/passado é absorvida de forma singular e especial em cada tempo histórico, em decorrência das vivências sociais específicas de cada época.

De acordo com Le Goff, o homem medieval introjecta em si o passado com tamanha intensidade que o passado é completamente incorporado no presente.

O presente é também saboreado pelo homem da Idade Média, que atualiza constantemente o passado, nomeadamente o passado bíblico. O homem da Idade Média vive num constante anacronismo, ignora a cor, reveste as personagens da Antiguidade de hábitos, sentimentos e comportamentos medievais. Os cruzados acreditavam que iam a Jerusalém vingar os verdadeiros carrascos de Cristo. Mas possamos dizer: "O passado não é estudado enquanto passado; ele é revivido e incorporado no presente”. (ROUSSET, 1951, p. 631) O presente já não é absorvido pelo passado, pois só este lhe dá sentido e significado? (LE GOFF, 2003, p. 222)

As palavras do autor explicitam o quanto os homens medievais se apropriaram do passado, especialmente no aspecto da religiosidade, para construir o seu presente. Na verdade, construíram o presente incorporando o passado e tornando-o seu presente. Esta presença do passado no presente é perfeitamente identificável nas aulas dos mestres universitários parisienses do século XIII, dentre eles particularmente o mestre Tomás de Aquino que usava, na mesma intensidade e importância, tanto os textos sagrados como os escritos do Filósofo (Aristóteles) para construir suas aulas e textos escolásticos.

O medievalista Marc Bloch, fundador da Escola dos Annales também nos ensina muito sobre a Idade Média, mas nos apresenta com grande maestria a importância do estudo da história e aponta para a importância de conhecê-la para conservarmos o conceito de 'homem' e de ‘sociedade'. 
Já não pensamos hoje, realmente, como o escrevia Maquiavel, como o pensava Hume ou Bonald, que há no tempo "uma coisa, pelo menos, que é imutável: o homem”. Aprendemos que também o homem mudou muito: no seu espírito e, provàvelmente, até nos mais delicados mecanismos do corpo. Como poderia ser de outro modo? Transformou-se profundamente a sua atmosfera mental; e também a sua higiene, a sua alimentação. Convimos, todavia, em que existe na natureza humana e nas sociedades humanas um fundo permanente. Se assim não fosse, os próprios vocábulos de "homem”e de "sociedade" não significariam coisa nenhuma. (BLOCH, 196?, p. 42)

Bloch explicita que os homens do presente são distintos dos do passado, pensam de modo diferente, constroem relações diferentes, os hábitos são novos, o conceito de corporeidade e de beleza se diferencia. Todavia, o passado permanece presente nas estruturas materiais e mentais do tempo atual e esta permanência Bloch designa como fundo permanente. Se a história e a memória do passado estiveram tão presentes no passado medieval, como indicou Le Goff, na passagem citada acima, indubitavelmente, o passado medieval também pode nos apresentar, para o nosso presente, belas lições sobre suas atitudes e instituições, especialmente àquelas relacionadas à educação dos homens. Com efeito, tal como a construção de uma casa necessita de um alicerce sólido, com vigas de ferro, argamassa, etc., para manter-se, nossas relações sociais, nossas instituições, no nosso caso, especialmente as educativas, precisam da memória e da história para ser construídas ou consolidadas.

É, pois, considerando os ensinamentos destes três autores mencionados e suas respectivas percepções de história e de memória que nos voltamos para o ambiente citadino medieval e para os dois documentos que nos propusemos analisar. O passado, história e memória, para nós é tudo isso que eles mencionaram: a possibilidade da virtude, da prudência, da memória individual e coletiva, de ser nosso fundo permanente. Entretanto, quando retomamos o passado medieval, as questões que nos inquietam são as do presente, porque somos sujeitos de nosso tempo e são a nossa história e memória que pretendemos construir e salvaguardar. Nossas questões estão vinculadas às escolas e universidades nas quais atuamos, cotidianamente, como profissionais do ensino e nas quais a todo o momento refletimos e fazemos indagações acerca do sujeito que estamos ajudando a construir, ao lado das demais relações sociais e instituições.

Voltemos, por meio da história, nosso olhar, primeiro para o cenário citadino medieval e, em seguida, para os dois documentos para, por meio deles, construirmos uma imaginem mental destes intelectuais medievais, não do que eles ensinaram propriamente, mas de como viveram. 
A história das cidades medievais ocupa grande espaço na historiografia, especialmente a francesa, mas não só, desde o século XIX. Já na primeira metade deste século encontramos o historiador Augustin Thierry investigando as origens das cidades na Idade Média e a analogia que este autor faz entre passado e presente é um bom exemplo de como podemos nos apropriar da história para construirmos nossas identidades.

Fala-se sempre para imitarmos nossos antepassados; seguimos, então, esse conselho? Nossos antepassados eram esses artesãos que fundaram as comunas, que idearam a liberdade moderna. Nossos antepassados não estavam distantes dos costumes atuais da América; eles tinham a simplicidade, bom senso, coragem civil. Deve-se a esses homens enérgicos o fato de toda a Europa ter-se tornado livre, há seis séculos; se o que desejavam não se concretizou, foi culpa da época e não deles: a barbárie era muito forte, por toda parte tinha raízes. No tempo em que a barbárie atribui para si, com direito exclusivo, a liberdade, a riqueza, a honra, poderia erguer facilmente uma outra liberdade, outras riquezas, outra honra, fora de seu domínio e contra ela? Um grito foi lançado pela civilização impaciente com seus entraves e subitamente a Europa ficou salpicada de nações novas, estranhas a tudo o que existia ao seu redor, uma buscando a outra para se unirem. [...] Todavia, se nossos antepassados não tiveram sorte, a coragem e a virtude nunca lhe faltaram [...]. (THIERRY, 1856, p. 3)

Evidentemente, precisamos ler as palavras de Thierry dentro do cenário de luta política na França da Restauração, quando os diversos segmentos sociais buscavam no passado, na história medieval, as origens da nação francesa. O autor descreve com muita propriedade a importância que as comunas (leia-se cidades), por conseguinte, seus habitantes, desempenharam no processo de libertação das amarras feudais e de como estes espaços tornaram-se espaços de liberdade, de luta, de coragem, pois, foi neles que a sociedade burguesa deitou suas raízes. Para Thierry, a sociedade burguesa é filha das comunas medievais e foi em seu seio que os atores sociais provocaram a ruptura com o sistema feudal. Neste sentido, o autor reconhece o passado como elemento essencial para a construção do presente. Do seu ponto de vista, é preciso legitimar a coragem da burguesia medieval para que a de seu tempo se considere, também, legitima, ou seja, Thierry incita os homens de seu tempo a retomarem a coragem dos seus antepassados medievais e lutarem pela liberdade no século XIX, do mesmo modo que os burgueses dos séculos XII e XIII o fizeram. Assim, Thierry tal como Osório Jeronymo, pede que se aprenda com a história, que se encare o passado como exemplo. 
Se Thierry chama a atenção para as lutas travadas no interior das comunas, para que seu tempo veja a história como um espelho no qual o seu presente pode-se mirar, um autor de nosso tempo (segunda metade do século XX) destaca o caráter eminentemente bélico do espaço citadino medieval. Não conseguimos identificar em sua análise o papel político das suas formulações, como vemos em Thierry. Todavia, nem por isso Rossiaud revela menos da situação das cidades medievais.

A história das cidades ocidentais está repleta de episódios de violência, de pavores ou de revoluções, [...] Essas lutas põem em confronto "magnatas" e "populares”; em Itália opõem verdadeiros partidos dominados por clãs e, nas cidades flamengas, transformam-se em verdadeiras lutas de classe, semeadas de massacres, exílios e destruições. Numerosas entre 1250 e 1330, provocaram em toda a parte a derrota dos antigos ricos e os alargamentos das oligarquias. [...] A derrota do povo não põe fim às tensões que, aqui e ali, se transformam em efêmeros momentos de terror, mas essas tensões exprimem-se constantemente em lutas "atomizadas", surdas, que se distinguem muito dificilmente da delinqüência comum. Pedras arremessadas, de noite, contra a janela de um patrão, rixas entre dois grupos de trabalhadores concorrentes, são facilmente associados pelos juízes à violência comum. (ROSSIAUD, 1989, p. 107)

Para Roussiaud, a ambiência citadina passa a ser o espaço comum da vida, mas é o do conflito ininterrupto. Há atritos de todas as ordens, senhores contra burgueses, jornaleiros contra seus patrões. Enfim, o embate é constante. O corriqueiro, como ele afirma, nesta sociedade que principia a ser comum, é o conflito. Mas, se por um lado a cidade é o espaço do conflito é também o de relações novas, se comparada as estruturas feudais. Se no feudo, no seio da ambiência rural, os homens estavam voltados para suas necessidades imediatas de sobrevivência, ou seja, produzia-se diretamente, ainda que não exclusivamente, somente para a sobrevivência, nas cidades medievais o sentido do trabalho se altera e a produção passa a ser mercantil.

As funções citadinas podem ser múltiplas (e cada vez mais se diversificam), mas o que impera é a mentalidade mercantil, que molda as sensibilidades e os comportamentos Como realçou R. Lopez, há muitos artesãos que são comerciantes em part time; o artesão assalariado vende as suas aptidões, o proprietário vende um quarto ou um terreno, o jurista vende os seus conhecimentos de direito, o professor vende a sua cultura, o operário vende a sua força física e a prostituta vende o seus corpo. A sua ministeria, os seus ofícios, são ordenados em função 
de um sistema de trocas recíprocas a que uns (os teólogos) chamam o bem comum e outros (os burgueses) chamam o mercado, segundo um preço justo estipulado diariamente em dinheiro, no mercado ou no local de recrutamento. (ROSSIAUD, 1989, p. 105)

Essa mudança no sentido prático do trabalho, pois os homens passam a produzir não mais para prover sua subsistência e de seu senhor, mas voltam-se para uma atividade direcionada à troca, ou seja, produz-se visando o mercado, verifica-se também uma transformação nas explicações mentais deste tempo. Os homens, nas cidades, de acordo com Rossiaud, mercantilizam tudo. Todo fazer humano pode ser vendável, inclusive o conhecimento. É em virtude desta nova mentalidade que o saber deixa de ser um dom divino e passa a ser, ele próprio, fruto do trabalho, portanto, passível de ser vendido, diferentemente do que fora até o século XII, como já observamos anteriormente. Todas as atividades são aceitas e justificadas porque estão voltadas para o bem comum da comunidade.

Na cidade, a fronteira moral essencial separa os que trabalham para a respublica dos outros trabalhadores. O cardeal Robert de Courson propõe que se exclua os ociosos do governo citadino; Dante reserva o lugar mais ínfimo no Além para aqueles que viveram sem infâmia e sem louvores

$[\ldots]$

No ano de 1260, em Augusta, Alberto Magno faz o elogio da cidade sólida e poderosa graças aos ricos que, em tempo de crise, asseguram a sua guarda, fornecendo armas e víveres aos trabalhadores que, sem eles, não poderiam sobreviver. (ROSSIAUD, 1989, p. 117)

O trabalho se transforma em uma atividade moralmente aceita e justificada por todos, pelos teólogos, escritores, mestres universitários. A atitude a ser condenada na ambiência citadina é ócio. Até mesmo a riqueza é um bem, porque por meio dela se protege a cidade, se conserva a milícia e, fundamentalmente paga a jornada do trabalho. $\mathrm{O}$ fato de um dos maiores mestres universitários como o fora Alberto Magno (o mestre de Tomás de Aquino) reconhecer a importância dos ricos na sociedade é uma mudança mentalidade sem precedentes ${ }^{1}$.

Um outro aspecto que merece ser destacado e expressa a profunda revolução mental que o ambiente citadino provocou nos homens do século

1 Ressalte-se que este comentário de Rossiaud acerca de Alberto Magno deve ser observado com cautela porque o mestre Alberto, foi um dos mais conhecidos mestres da Ordem dos mendicantes dominicanos, ou seja, fez voto de pobreza, portanto, defender a riqueza seria algo contrário ao que a Ordem e ele próprio pregavam. Contudo, certamente, o mestre considerou, sempre de suma a importância o cuidado com a respublica e, sob este aspecto poderia ter valorizado a riqueza, desde que útil a comunidade. 
XIII foi a aceitação, por homens da Igreja, de atividades que até então haviam sido veemente condenadas, como a das prostitutas. Em virtude das mudanças mentais e materiais, esta atividade passa a ser legitimada como um bem público.

Na época de Franco Sacchetti, os padres da cidade consideravam as prostitutas duplamente necessárias: contribuíam para refrear a violência e protegiam a honra das virgens e das mulheres casadas e punham, igualmente, um travão - aspecto tão importante como o primeiro - às loucuras sentimentais. (ROSSIAUD, 1989, p. 115)

A prostituição, atividade tão condenada na história, particularmente no interior do pensamento cristão, torna-se útil à vivência citadina porque protegeria e contribuiria para a preservação do estado de pureza das virgens, 'apaziguando' o espírito dos jovens. Colaborava, assim, para a paz mental, já que a material era dominada pela instabilidade mercantil.

É, pois, neste contexto citadino de mudanças mentais e estruturais profundas que assistimos ao surgimento de um dos maiores movimentos religiosos e intelectuais da Idade Média, as Ordens Mendicantes. Estas ordens surgiram em oposição às atitudes da Igreja e de seus representantes que se voltavam cada vez mais para a riqueza e o luxo terreno, em detrimento dos consagrados valores cristãos. Quatro ordens surgem no século XIII: os Franciscanos, os Dominicanos, os Carmelitas e os Agostinianos, mas as duas primeiras foram as que mais se destacaram. Este movimento tem como características principais o voto de pobreza e a pregação/evangelização. Todavia, especialmente os dominicanos se dedicam, com afinco, aos estudos e as investigações científicas, aliás, dois dos principais mestres da Universidade parisiense, Boaventura de Bagnoregio e Tomás de Aquino saem delas.

Le Goff, em sua obra Uma Longa Idade Média, chama-nos a atenção para o fato de que as ordens e as cidades fazem parte do mesmo processo. De acordo com o autor, o século XIII foi "o século do nascimento do urbanismo e do patriotismo urbano” (LE GOFF, 2008, p. 187). O Ocidente se urbaniza sob o olhar e a pregação dos mendicantes. Em muitas cidades se propõe que as mesmas sejam geograficamente organizadas e divididas a partir das Ordens Mendicantes. Cada uma das ordens construiria seus espaços de pregação e de oração. Segundo o autor (2008, p. 187), existiu uma proposta, em fins do século XIV, para que as cidades da latinidade cristã tivessem uma praça principal e nela seria construída e a principal central e depois haveria mais quatro praças com suas respectivas igrejas para cada uma das ordens (dominicanos, franciscanos, 
agostinianos e carmelitas). A abordagem de Le Goff nos explicita o quanto as ordens foram importantes para a construção das cidades medievais seja sob o aspecto material, seja o mental. Com efeito, não podemos nos esquecer que os mestres universitários eram, a partir da segunda metade do século XIII, na sua maioria, oriundos das ordens franciscanas e dominicanas.

As ordens mendicantes, assim, parecem ter "ocupado" todo o espaço urbano da cristandade, a tal ponto que o mapa dos conventos de mendicantes se confunde com o mapa das cidades. E o "critério mendicante" pôde se tornar o melhor meio de localizar os pontos da rede urbanas [...]. (LE GOFF, 2008, p. 181)

A passagem de Le Goff exemplifica ainda mais a importância das ordens para a ambiência e configuração das cidades, pois, onde existiram mosteiros, existiram cidades. Aliás, são estes que permitem, segundo o autor, a localização das cidades. Suas palavras permitem-nos pensar em quase uma simbiose entre cidades e ordens no século XIII.

Após tecermos considerações sobre a perspectiva de nosso olhar para com a história, a memória, deixarmos explicito qual nosso caminhar pela história da educação e termos traçados, em linhas gerais, um quadro sobre as cidades medievais passaremos agora a análise dos dois documentos em tela.

O primeiro documento a ser analisado é a Authentica Habita (Posturas Autenticas). Nela o imperador Frederico Barbaroxa edita um decreto protegendo os homens de saber. Como o documento é pouco extenso e também pouco conhecido o inserimos na integra no texto.

O imperador Frederico. Tendo havido um diligente exame dos bispos, dos abades, dos chefes (generais) e de todos os juízes e de próceres (grandes) do nosso palácio sobre isto, concedemos a todos os alunos que iniciam (peregrinam) na causa dos estudos, e principalmente aos mestres (professores) das divinas e sagradas leis esse benefício da nossa piedade, a fim de que, nos lugares em que se exercitam (praticam) os estudos das letras (literaturas), tanto os mesmos quantos seus mensageiros (intérpretes) venham e habitem seguros nos mesmos (lugares). De fato consideramos digno que, como fazendo o bem mereçam o nosso louvor e a nossa proteção, por uma especial dileção (afeto) defendamos de toda injustiça (injustiça) a todos aqueles por cuja ciência o mundo é iluminado e a vida dos súditos (sujeitos) é informada para que obedeçam a Deus e a nós, ministros dele.

Quem não se compadecerá deles? Tendo sido expulsos pelo amor da ciência, pobres de bens se exaurem (esgotam) a si mesmos, expõem suas vidas a todos os perigos, $\mathrm{e}-\mathrm{o}$ que deve ser tido como muito grave 
- sofrem (recebem) muitas vezes ofensas (injúrias) corporais por porte de homens muito vis (sem valor), se motivo algum.

Por isso, decretamos esta lei geral e válida para sempre, que ninguém de agora em diante seja encontrado tão audaz que presuma produzir alguma injustiça (injúria) contra os alunos (estudantes), nem provoque contra eles algum dano, por causa de dívida de alguém da mesma província, o que de vez em quando ouvimos ter sido feito por um perverso costume.

A todos os que negligenciarem conhecer esta sagrada lei e o tempo dela, se descuidarem de reivindicar isto, os reitores dos lugares, será exigida de todos (reitores) a restituição das coisas furtadas ao quádruplo, e, aplicada a nota de infâmia pelo mesmo direito, percam eles para sempre a sua dignidade (cargo).

Mas, se alguém quiser mover ação contra eles por algum negócio, pela opção dada aos alunos a respeito desta situação, convém que os mesmos compareçam diante do senhor, ou do seu mestre, ou do bispo da mesma cidade, aos quais concedemos jurisdição para isso. Quem, porém, tentar levá-los a outro juiz, mesmo que a causa seja justíssima, caia (sucumba) por tal ímpeto.

Ordenamos, contudo, inserir esta lei entre as constituições imperiais sob o título "Não (há) filho a favor (ou em lugar) do pai etc.” (Cod, 4,13 post 1.5 )

O primeiro aspecto que deve ser assinalado é o fato de um governante, em meados do século XII, se sensibilizar pelos homens do saber e edita uma lei com vistas a proteger estudantes e mestres. É preciso considerar o tempo histórico em que o documento veio à luz porque é o momento em que o Ocidente medieval vive o renascimento das cidades, a organização do comercio e o estabelecimento de escolas citadinas. Ainda que todos estes processos de mudanças estejam ocorrendo com grande intensidade, as atividades do ensino/ conhecimento ainda são frágeis na ambiência citadina. Não está muito explicito qual o papel dos homens do saber neste contexto; daí a necessidade de proteção. Também este é um tempo de muita insegurança na sociedade. O comércio sofre constantes assaltos e pilhagens, o direito romano está sendo retomado, mas ainda predomina nas leis o direito canônico. Em última instância, as leis civis e laicas estão sendo retomadas e validadas.

Um segundo aspecto do documento que deve ser considerado diz respeito à valorização das atividades vinculadas ao conhecimento. Do ponto de vista do Imperador, o conhecimento, as letras são importantes para o seu Império porque elas possibilitam que os homens compreendam melhor a natureza e as coisas divinas. Desse modo, os homens de saber, ao produzirem o conhecimento, fazem o bem ao conjunto da sociedade na medida em que com a sua 
'ciência o mundo ilumina'. Por trazerem este bem para o conjunto da sociedade merecem a afeição de todos e precisam ser protegidos de todas as injustiças. Esta proteção incide sobre atividades especiais da vida estudantil do século XII, como as viagens, as perseguições locais.

Um terceiro ponto da lei que deve ser salientado vincula-se à própria vida material dos estudantes e mestres. Como homens de ‘ciência’ não possuíam fonte de sobrevivência por isso necessitavam que a sociedade arcasse com seu sustento e, isso implicaria no pagamento de uma espécie de ‘salário’ que asseguraria a sobrevivência destes homens posto que 'pobres de bens se exaurem (esgotam) a si mesmos'. Sob este aspecto do pagamento, verificamos, no documento, as origens do salário dos mestres universitários do século XIII. Na verdade, o documento do imperador já aponta para uma leitura nova da sociedade em relação aos homens do saber.

Um último e importante aspecto que deve ser ressaltado no documento é a liberdade que os homens de 'letras' conquistaram com esta lei. O fato de alunos e mestres poderem circular pelas principais cidades do Ocidente cristão no século XII (Paris, Bolonha, Oxford) é uma conquista muito grande, pois os sujeitos nesta sociedade medieva precisavam pagar pedágios, eram pilhados, sofriam as vicissitudes dos poderes locais e das jurisdições senhoriais de cada feudo. Desse modo, a Authentica .... ao assegurar o direito de ir e vir e, ao mesmo tempo, afiançar que os alunos e mestres somente poderão ser julgados por juizes especiais, se estabelece uma proteção e uma liberdade para um segmento da sociedade que, até então, nenhum outro segmento da sociedade havia conquistado. Ainda que estas medidas possam ser consideradas privilégios especiais para nós, atualmente, indubitavelmente naquele tempo eram necessárias porque assegurava aos homens que se dedicavam aos estudos condições de sobrevivência.

Como Frederico I, Barba Roxa, afirmou em 1155, na sua lei fundamental sobre liberdades acadêmicas, <<é pela aprendizagem que o mundo se ilumina e que as vidas dos súditos são modeladas na obediência a Deus e ao seu Servo o imperado [...]>>. Esta formulação retórica delineava com grande precisão as expectativas dualistas do mais alto poder terreno. O simbolismo da luz, tão popular na Idade Média, pretende transmitir a idéia segundo a qual a instrução enriquece o conhecimento e proporciona estabilidade a ordem social. (RÜEGG, 1996, p. 13-14)

As palavras de Rüegg não deixam dúvidas sobre a importância desta lei para os homens do saber cristão latino. Revela, também, o quanto esta sociedade 
estava se aproximando do conhecimento e fazendo uso dele para a organização das relações sociais. Neste sentido, o saber estava, gradualmente, deixando de ser um dom divino e tornando-se uma atividade humana/terrena, necessária ao bom convívio de todos nas cidades.

Após tecer estas considerações sobre a Athentica ..., passaremos para o segundo documento em tela, o Estatuto da Universidade de Sorbone.

Segundo nota de Denifle, este documento ou, ao menos a primeira parte dele, foi redigida por Roberto de Sorbona, em 1274: "Prima pars Statutorum composita est a Roberto de Sorbona ante 15 Augsuti na 1274”2. Como se trata de um documento mais longo, reproduziremos algumas passagens para que se tenha uma idéia de como a vida era regulada na Universidade de Sorbone.

Quero que seja obedecido, na íntegra, o uso (costume = consuetudo) que foi instituído nesta casa (escola) desde o início pelo conselho dos bons, e se algo foi transgredido até agora, não se presuma transgredilo daqui para frente. (Chartularium ... doc. $\mathrm{n}^{\circ}$. 448. Trad. livre)

O primeiro parágrafo do documento nos aponta para as especificidades do documento. Está explicito nele que a intenção é organizar e regrar a vida dos estudantes que habitam as universidades. Sob este aspecto, é importante salientar que as universidades medievais do século XIII, na sua maioria, eram organizadas na forma de internato, ou seja, os alunos viviam na 'casa'; seriam, portanto, similares aos colégios internatos da modernidade. O primeiro parágrafo aconselha todos seguirem os costumes da casa, não se devendo promover a transgressão dos hábitos estabelecidos.

Mais adiante encontramos a proibição da entrada de pessoas estranhas na casa, a menos que estas se submetam às suas regras.

Ninguém seja recebido na casa (escola), a não ser que prometa fidelidade, que se acontecer isso de o mesmo receber os livros da comunidade, que como seus assim os observará fielmente, e de modo algum os esquecerá nem os deixará guardado fora da escola, e integralmente os devolverá em qualquer tempo em que forem exigidos pela escola e quando acontecer de sair da vila. (Chartularium ... doc. $\mathrm{n}^{\circ}$. 448. Trad. livre)

\footnotetext{
2 Este documento foi extraido da obra Chartularium Universitatis Parisiensis publicado por Henricus Denifle em 1899. Neste texto estamos utilizando a reedição de 1964. Trata-se do documento $\mathrm{n}^{\circ} .448$ do Tomo I, p. 505-514. Assim, informamos que não indicaremos as páginas em específico, mas remetermos, nas citações, ao ano e número do documento.
} 
O documento destaca um cuidado intenso com os livros da comunidade, o que denota a existência de uma biblioteca pela qual todos eram responsáveis.

O estatuto explicita também a mentalidade das ordens mendicantes presentes na comunidade universitária quando nos remete para o vestuário dos alunos, pois estes não podem ostentar luxo. Ao contrário, devem se vestir simplesmente nos moldes dos frades franciscanos e dominicanos. "Igualmente todos tenham a grande túnica fechada sem adereços.

De igual modo ninguém tenha veste talar ou vestes nobres, pelo que possa de algum modo provocar escândalo”. (Chartularium ... doc. nº. 448. Trad. livre)

Outro aspecto revelado no Estatuto é a existência de alunos pobres, que residem na casa, mas não têm dinheiro para pagar a moradia. A passagem a seguir pressupõe a existência de pessoas que pagavam para habitar na universidade.

Igualmente está estabelecido que aqueles que permaneceram na casa (escola) à custa da casa, o quanto antes se previnam e em breve tempo se preparem e se disponham a serem profissionais em sermões e discursos públicos pelas paróquias, nas disputas e leituras publicas nas escolas; caso contrário serão privados totalmente dos benefícios da casa (escola). Embora faça isso em virtude do privilégio: contudo advirto-os antes caridosamente. Verdadeiramente a respeito daqueles que são recebidos novamente, ou que devem ser recebidos, está estabelecido de tal maneira que, se não se profissionalizarem nos sermões (falas), disputas e leituras, como foi dito, similarmente serão despojados abaixo do sétimo ano do tempo de sua recepção. (Chartularium ... doc. $\mathrm{n}^{\circ}$. 448. Trad. livre)

Os alunos pobres estudam e habitam na universidade, mas precisam estar dispostos a ensinar e pregar para conservar seu sustento, ou seja, pela pregação e pelo ensino pagam os custos de sua manutenção na casa. Aliás, é bastante interessante observar que mesmo para estes alunos há uma tolerância para permanecerem na universidade usufruindo do ensino e da moradia por sete anos.

Em outra passagem do Estatuto encontramos a preocupação em conservar a privacidade, a paz e o silêncio da casa e para que isso seja mantido, o documento explicita que entrada de pessoas de fora da comunidade universitária, ou seja, da cidade seja muito restrita em cada um dos espaços da casa.

De igual modo, para a paz e utilidade, explicamos que ninguém do século (não consagrado) morador na vila, escritor, corredor ou qualquer outro, sem um grande motivo, coma, fique deitado no quarto ou permaneça com os sócios comensais, nem converse com freqüência nos jardins, no pátio ou ouros lugares da casa, a fim de que a priva- 
cidade da casa e a conversação dos sócios (companheiros) fiquem expostas. (Chartularium ... doc. $\mathrm{n}^{\circ}$. 448. Trad. livre)

O Estatuto nos revela as minudências da vida escolar, inclusive no que diz respeito às multas a serem pagas por aqueles que não obedecessem as regras da casa. O que se evidencia é que as transgressões em si eram punidas, mas tornavam-se mais graves quando poderiam se transformar em exemplos de comportamento para outras pessoas. Verifica-se, assim, uma preocupação muito grande em cercear os 'maus hábitos' de forma a manter a harmonia da casa. A passagem abaixo é um exemplo.

Na verdade, a pena dos transgressores dos estatutos que não estão sob juramento, é de dois denários se não forem surpreendidos por outro; se, porém, forem surpreendidos, a pena é de seis denários para aqueles que são obrigados a guardar dinheiro. Entendo que o não surpreendido, se antes que a notícia tenha chegado ao prior, o mesmo se acuse ao prior ou tenha confessado ao clérigo, que sobre o mesmo estabeleça dois denários por tal emenda, pois não é suficiente dizer aos sócios: “eu me acuso”. Isto não passe nem seja conservado. (Chartularium ... doc. $\mathrm{n}^{\circ}$. 448. Trad. livre)

Se a infração não fosse testemunhada por outros, o valor da multa era um, mas se companheiros tivessem visto, o preço se elevava porque os demais poderiam cometer as mesmas faltas.

Inúmeras são as passagens do Estatuto que tratam do comportamento de seus moradores. Na verdade, o documento revela um cuidado com o corpo, a limpeza, o comportamento, o vestuário, a paz necessária ao estudo. Em última instância, o Estatuto apresenta regras de comportamento que buscavam ordenar a vida cotidiana da comunidade universitária e, dentre essas regras, há várias que tratam do convívio com o dinheiro, ou seja, fica nítida a presença também na comunidade acadêmica da mentalidade mercantil do século XIII, já apontada anteriormente. A universidade, tal como a cidade, vivencia, acompanha e produz o movimento de transformações sociais pelo qual o Ocidente medievo estava passando. Não é, portanto, um fenômeno à parte, mas, parte integrante do processo histórico.

Para concluir nosso estudo destacamos o fato de que a análise dos documentos pela lente da história, enquanto exemplo vivido, possibilita-nos perceber o processo de transformação pelo qual os homens do conhecimento passaram entre os século XII e XIII. Quando as cidades e o comércio principiavam os seus movimentos de ascensão, no século XII, temos a Authentica Habita promovendo a proteção e a liberdade destes homens. No entanto, no século XIII, 
quando as cidades conquistaram, gradativamente a liberdade e a autonomia em relação aos seus senhores, as universidades, por conseguinte, os homens de saber preocupam-se com regras para suas existências cotidianas de acordo com os novos tempos. A lição que podemos depreender destes dois documentos é que tanto uma instituição educativa como as pessoas adquirem corpus e sustentabilidade quando os indivíduos e a sociedade trilham por caminhos similares.

\section{Referências}

ABERLARDO, Pedro. História das minhas calamidades. In: Os pensadores. São Paulo: Abril Cultural, 1973. p. 249-278.

BLOCH, Marc. Introdução à história. Lisboa: Publicações EuropaAmérica, 1965.

DENIFLE, Henricus. Primaeva statuta domus Sorbone. In: Chartularium Universitatis Parisiensis. Bruxelles: Culture et Civilisation, 1964. Tomus I, p. 505-514.

FREDERICI I, IMPERATORIS. Authentica Habita/Privilegium scolasticum. In: Monumenta Germaniae. Leges, II, p. 114. Disponível em: <www. veritatis-societas.org>. Acesso em: 12 set. 2004.

LE GOFF, Jacques. As ordens mendicantes. In: média. Rio de Janeiro: Civilização Brasileira, 2008. p. 173-189.

LE GOFF, Jacques. Passado/Presente. In: . Memória e história. Campinas: Ed. da Unicamp, 2003. p. 207-233.

MACEDO, Duarte Ribeiro de. Sobre a introdução das artes. In: SÉRGIO, António (Org.). Antologia dos economistas portugueses. Século XVII. Lisboa: Sá da Costa, 1975. p. 207-233.

OSORIO, Jeronymo. Da vida e feitos d'el Rei D. Manoel. Lisboa: Na Impressão Regia por ordem superior, 1804. 3 v.

ROSSIAUD, Jacques. O citadino e a vida na cidade. In: LE GOFF, Jacques (Dir.). O homem medieval. Lisboa: Presença, 1989. p. 99-122.

RÜEGG, Walter. Temas. In : RIDDER-SYMOENS, Hilde (Coord.).Uma história da Universidade na Europa. Lisboa: Imprensa Nacional, 1996. v. 1. As Universidade na Idade Média. p. 3-31.

THIERRY, Augustin. Dix ans d'études historiques. Paris: Furne, 1856. 